\title{
Antioxidative and antimutagenic effects of Panicum miliaceum L.
}

\author{
Jeong Seob Park ${ }^{1 \ddagger}$, Jong Soon Lee ${ }^{2 \ddagger}$, Jeong Ho Lee ${ }^{3 *}$ \\ ${ }^{1}$ The Food Industry Promotional Agency of Korea, Iksan 54576, Korea \\ ${ }^{2}$ Department of Beauty Coordination, Chungnam State University, Cheongyang 33303, Korea \\ ${ }^{3}$ Sunchang Research Institute of Health and Longevity, Sunchang 56015, Korea \\ 기장의 항산화 활성 및 항돌연변이 효능 \\ 박정섭 $^{1 \ddagger} \cdot$ 이종순 ${ }^{\ddagger} \cdot$ 이정호 ${ }^{3 *}$ \\ ${ }^{1}$ 한국식품산업클러스터진흥원, ${ }^{2}$ 충남도립대학교 뷰티코디네이션학과, ${ }^{3}($ 재 $)$ 순창건강장수연구소
}

\begin{abstract}
The antioxidative and antimutagenic effects of a $80 \%$ methanol extract of Panicum miliaceum were examined using the 2,2-diphenyl-1-picrylhydrazyl (DPPH) radical scavenging assay, determination of the total polyphenol content, and the Ames test using Salmonella typhimurium. The DPPH radical scavenging activity $\left(\mathrm{EC}_{50}\right)$ and total polyphenol content of the $80 \%$ methanol extract of $P$. miliaceum were $67.43 \pm 4.28 \mu \mathrm{g} / \mathrm{mL}$ and $16.26 \pm 1.02 \mathrm{mg} / \mathrm{g}$, respectively. The $80 \%$ methanol extract was sequentially fractionated using chloroform, $n$-butanol, and water, and the chloroform fraction was found to exhibit strong antioxidative effects. The antimutagenic effects of $P$. miliaceum against aflatoxin B1, 3-amino-1,4-dimethyl-5H-pyrido[4,3-b]indole, and 2-aminofluorene were then studied by the Ames test using S. typhimurium TA98 and TA100. The results obtained using the $80 \%$ methanol extract $(600 \mu \mathrm{g} / \mathrm{plate})$ and $S$. typhimurium TA98 and TA100 showed 95.2 \pm 2.3 and 89.8 $\pm 4.5 \%$ inhibition of mutations caused by AFB $_{1}$, respectively. Similarly, the chloroform fraction (200 $\mu \mathrm{g} /$ plate) exhibited a $>90 \%$ inhibition for both strains. These results therefore indicate that $P$. miliaceum exhibits both mutagenic and antioxidant activities, thereby rendering it suitable for use in a variety of food materials.
\end{abstract}

Key words : Panicum miliaceum, antioxidative, antimutagenicity, S. typhimurium TA98, S. typhimurium TA100

서 론

현대인들의 건강에 대한 관심이 고조되면서 건강한 식 생활을 위하여 기장 등 잡곡의 섭취가 증가하고 있다 (Rimm 등, 1996; Kwak 등, 2004). 기장(Panicum miliaceum L.)은 인류가 가장 오래 재배한 작물로 외떡잎식물 벼목 화본과의 한해살이 초본으로 척박한 환경에서도 적응성 이 높고, 재배 기간이 짧아 온대에서 아열대에 이르기까지 광범위한 지역에서 재배한다(Kim 등, 2016; Kim 등, 2017;
Kang 등, 2019; Yun 등, 2019). 주성분은 당질, 단백질, 지방 질, 식이섬유, 비타민 $\mathrm{A}$, 무기성분 등의 영양성분이 함유되 어 인체 건강증진에 유익한 농작물이다 $(\mathrm{Ha}$ 와 Lee, 2001; $\mathrm{Kim}$ 등, 2017). 식물계에 널리 분포되어 있는 페놀성 화합물 은 다양한 화학구조와 분자량을 가지며, phenolic hydroxyl 기가 단백질 등 거대분자와 결합하여 항산화, 항암, 항균 등 생리활성을 가진다. 곡류에 함유되어 있는 polyphenolic 화합물은 우수한 항산화 활성을 가지고 있다(Middleton과 Kandaswami, 1994; Rice-Evans 등, 1997). Ames 세균시험계

\footnotetext{
*Corresponding author. E-mail : wooju1119@naver.com, Phone : +82-63-653-8708, Fax : +82-63-653-8710

${ }^{\dagger}$ These authors contributed equally to this work.

Received 25 February 2020; Revised 26 March 2020; Accepted 07 April 2020.

Copyright (c) The Korean Society of Food Preservation.

This is an Open Access article distributed under the terms of the Creative Commons Attribution Non-Commercial License (http://creativecommons.org/licenses/by-nc/4.0) which permits unrestricted non-commercial use, distribution, and reproduction in any medium, provided the original work is properly cited.
} 
는 Salmonella를 이용해 돌연변이 유발물질이나 산화물질 억제 등에 대한 시험법으로 항돌연변이 효능을 측정한다. 사용되는 균주는 구조돌연변이원(frame shift mutation)인 $S$. typhimurium TA98과 염기쌍치환돌연변이원(base-substitute mutation)인 S. typhimurium TA100이 이용된다(Maron와 Ames, 1983). 이러한 방법으로 검색된 활성 물질은 동물세 포에서도 $80 \%$ 이상 효능을 발휘하여 천연물질을 검색하는 데 널리 이용되고 있다(Zeiger, 1987). Aflatoxin $\mathrm{B} 1\left(\mathrm{AFB}_{1}\right)$ 의 암 유발 원인은 생체내 간의 microsomal enzyme system 가운데 mixed function oxidase에 의해 대사 활성화되어 친 전자성인 핵산이나 단백질과 함께 첨가 생성물을 형성하 여 불활성 또는 돌연변이를 일으킨다(Singer와 Grunberger, 1983). 아플라톡신은 인체에 노출되면 발암원으로 작용하여 간암 발생을 약 60배 증가시킨다(Eaton과 Gallagher, 1994). 3-Amino-1,4-dimethyl-5H-pyrido[4,3-b]indole(Trp-P-1)은 단백 질과 지방을 함유하고 있는 식품을 굽거나 튀길 때 많이 발생한다. 특히 생선이나 패스트푸드에 함유되어 돌연변 이원으로 섭취하는 물질이다(Weng 등, 2007). Trp-P-1은 심장의 모세관이나 관상동맥과 결합하고, 신장에서 사구 체의 모세혈관 소동맥과 결합한다. 이는 $\mathrm{P} 450_{1} \mathrm{~A}$ 의 $\mathrm{BNF}$ inducible enzyme에 의해 활성화됨과 동시에 헤테로 고리형 아민으로 변형되어 돌연변이원으로 작용한다(Yamaizumi 등, 1980). 2-Aminofluorene(2-AF)은 디젤엔진이나 화석연 료의 불완전 산화에 의해 발생되는 nitro-화합물로써 DNA adduct를 형성하여 암을 유발시키는 것으로 알려져 있다 (Xue과 Warshawsky, 2005).

새만금은 우리나라 최대 간척지로 개발이 완료되면 농 업용지 중 약 $52 \%$ 인 4,469 ha가 곡물생산을 위한 친환경첨 단농산업단지로 조성되는 것으로 계획되어 있다. 간척지 에 재배 가능한 농작물 연구는 대부분 벼농사 위주이었으 나, 최근에는 밭작물에 대한 연구가 증가하고 있다(Jung 등, 2014; Kang 등, 2019). 간척지에 재배할 수 있는 기능성 농작물의 발굴은 우리나라 미래 농업발전에 크게 이바지 할 수 있다(Kang 등, 2019). 이에 따라 간척지에 재배 적합 한 작물을 발굴하고, 부가가치를 상승시키기 위한 품질 향상 및 기능성 연구가 필요하다. 간척지에 재배하는 작물 은 품질과 기능면에서 다른 환경에서 재배한 작물보다 우수한 기능성을 갖추어야 한다. 농촌진흥청에서 새만금 간척지 토양의 염 농도를 측정한 후, 재배 가능한 작물을 연구한 결과, 기장은 토양 염 농도 $0.3 \%$ 에서도 생육할 수 있으며, 개간지, 척박지, 가뭄 등 척박한 환경에서도 잘 자라고, 생육기간이 70 일에서 110 일 정도이며, 물이 적어 도 잘 재배된다(Ha와 Lee, 2001; Jung 등, 2014; Yoon 등, 2015; Choi 등, 2016; Kim 등, 2016; Kang 등, 2019). 기장은 현대인의 건강에 유익하여 전북에서 재배면적이 증가하 고 있어 전북지역에서 재배된 기장에 대한 항산화 활성과
항돌연변이원성을 측정하여 보고하는 바이다.

\section{재료 및 방법}

\section{시료 제조}

본 연구에 사용된 기장은 2017년 전북 완주에서 재배한 기장(Panicum miliaceum L. cv. Ibaekchal)을 빛깔, 모양, 크기 등 외부형태를 육종학 전문가에게 감수 확인한 후 동결건조기(IlShinBioBase LP20, Dongducheon, Korea)를 이용하여 건조하였다. 건조된 기장을 $50 \mathrm{mesh}$ 로 분쇄한 후 5 배의 $80 \%$ 메탄올을 가하여 $45^{\circ} \mathrm{C}$ 에서 6 시간 동안 3 회 진탕추출한 후 $0.4 \mu \mathrm{m}$ 필터로 여과시킨 후 감압농축기 (Eyela N-1000, Tokyo, Japan)로 $45^{\circ} \mathrm{C}$ 에서 메탄올을 제거한 후 동결 건조하였다. 용매 분획은 기장 $80 \%$ 메탄올 추출물 을 초순수로 현탁한 후 클로로포름과 수포화 $n$-부탄올 순 으로 분획한 후 농축시켜 $-20^{\circ} \mathrm{C}$ 에 보관하면서 실험에 사 용하였다.

\section{재료 및 시약}

항산화 활성 측정은 2,2-diphenyl-1-picrylhydrazyl(DPPH) 와 Folin-Ciocalteu's phenol reagent는 Sigma-Aldrich(St. Louis, MO, USA)사 제품을 사용하였다. 항돌연변이원성 측정을 위해 aflatoxin $\mathrm{B} 1,3$-amino-1,4-dimethyl-5H-pyrido [4,3-b] indole, 2-aminofluorene 등은 Sigma-Aldrich(St. Louis, $\mathrm{MO}, \mathrm{USA}$ )사 제품, monooxygenase(cytochrome P450) 활성 을 위해 rat에 투여한 $\beta$-naphthoflavone과 phenobarbital, S9 mix를 제조하기 위한 NADP( $\beta$-nicotinamide adenine dinucleotide phosphate), D-glucose-6-phosphate, dimethyl sulfoxide (DMSO)는 Sigma-Aldrich(St. Louis, MO, USA)사 제품을 사용하였으며, 기타 시약은 1급 이상을 사용하였다. Salmonella typhimurium TA98(hisD3052)과 TA100(hisG46) 은 한국생명공학연구원 유전자은행에서 분양받아 사용하 였다.

\section{$\mathrm{DPPH}$ 라디칼 소거활성 측정}

$\mathrm{DPPH}$ 라디칼 소거활성은 Okawa 등(2001)의 방법에 준 하여 실시하였다. $0.15 \mathrm{mM} \mathrm{DPPH}$ 용액 $1 \mathrm{~mL}$ 에 시료용액을 농도별로 $0.1 \mathrm{~mL}$ 를 혼합하여 $37^{\circ} \mathrm{C}$ 에서 30 분 동안 반응시 킨 후, 분광광도계(UV-1601, Shimadzu, Japan)를 이용하여 $517 \mathrm{~nm}$ 에서 흡광도를 측정하였다. 각 시료의 농도에 따른 $\mathrm{DPPH}$ 라디칼을 소거한 후 잔존하는 $\mathrm{DPPH}$ 라디칼을 $50 \%$ 줄일 수 있는 농도 $\left(\mathrm{EC}_{50}\right)$ 로 계산하였다.

\section{총폴리페놀 함량 측정}

총폴리페놀 함량은 Slinkard와 Singleton(1977)의 방법을 일부 변형하여 측정하였다. 추출물 $0.5 \mu \mathrm{g} / 10 \mathrm{~mL}$ (DMSO) 
농도로 용해시킨 시료추출액 $200 \mu \mathrm{L}$ 와 증류수 $1.8 \mathrm{~mL}$, Folin-Ciocalteu's phenol regent $200 \mu \mathrm{L}$ 를 혼합하여 5 분간 반응시킨 후, $7 \% \mathrm{Na}_{2} \mathrm{CO}_{3} 2 \mathrm{~mL}$ 와 증류수 $0.8 \mathrm{~mL}$ 를 혼합한 다음 실온에서 90 분 동안 반응시킨 후 $750 \mathrm{~nm}$ 에서 흡광도 를 측정하였으며, gallic acid(Sigma Aldrich Co., MO, USA) 의 검량선에 의하여 함량을 측정하였다.

\section{S9 분획 제조}

S9 분획 조제는 Ong 등(1980)의 방법에 따라 조제하였으 며, 실험용 동물은 $200 \pm 10 \mathrm{~g}$ 의 7주령된 rat(male, Sprague Dawley, 대전실험동물), 유도물질로는 phenobarbital, $\beta$ naphtoflavone을 사용하였다. 조제된 $\mathrm{S} 9$ 분획은 $0.5 \mathrm{~mL}$ 씩 분주하여 $-70^{\circ} \mathrm{C}$ 에 보관하면서 사용하였고, $\mathrm{S} 9 \mathrm{mix}$ 는 Maron 와 Ames(1983)의 방법에 따라 조제하였다.

\section{항돌연변이원성 시험}

항돌연변이원성 측정은 Ames와 Maron(1983)의 Ames test를 개량한 preincubation 방법으로 실시하였다. 멸균시 킨 시험관에 변이원 $50 \mu \mathrm{L}, 0.1 \mathrm{M}$ sodium phosphate buffer $0.5 \mathrm{~mL}(0.5 \% \mathrm{~S} 9 \mathrm{mix} 0.5 \mathrm{~mL})$, 기장 추출물 $50 \mu \mathrm{L}$ 와 Oxoid Nutrient Broth No. 2(Oxoid Co. Ltd., Hampshire, England)에 12 시간 배양시킨 균 배양액 $\left(1-2 \times 10^{9} \mathrm{CFU} / \mathrm{mL}, \mathrm{OD} 0.4\right)$ $100 \mathrm{~mL}$ 를 혼합하고, $37^{\circ} \mathrm{C}$ 에서 $210 \mathrm{rpm}$ 으로 20 분간 진탕 배양하였다. 배양액에 $0.5 \mathrm{mM}$ histidine과 biotin을 함유한 top agar $2 \mathrm{~mL}$ 를 혼합한 후 minimal glucose agar plate(agar $15 \mathrm{~g}$, 멸균수 $930 \mathrm{~mL}, 50 \times \mathrm{VB}$ salt $20 \mathrm{~mL}, 40 \%$ glucose $50 \mathrm{~mL}$ )를 평판 배지 상에 도포하여 $37^{\circ} \mathrm{C}$ 에서 48 시간 배양 하여 발생한 복귀 돌연변이주( is $^{+}$revertant colony)의 수를 계수하여 돌연변이 억제 효능을 평가하였다. 돌연변이 억 제 효능은 아래와 같이 계산하였으며, 각각의 실험은 2 plate씩 3 반복 실시하였다.

$$
\text { 돌연변이 억제 }(\%)=\frac{\left[\left(\mathrm{M}-\mathrm{S}_{0}\right)-\mathrm{S}_{1}\right]}{\left(\mathrm{M}-\mathrm{S}_{0}\right)} \times 100
$$

M: The number of revertants only in presence of mutagen

$\mathrm{S}_{0}$ : The number of spontaneous revertants

$\mathrm{S}_{1}$ : The number of revertants in presence of mutagen and sample

\section{통계 분석}

통계분석은 SPSS 통계 프로그램(Statistical Package for the Social Science, Ver. 12.0, SPSS Inc., Chicago, IL, USA) 을 이용하여 각 측정군의 평균과 표준편차를 산출하고 처 리간의 차이 유무를 one-way ANOVA(analysis of variation)
로 분석한 후 Duncan's multiple range test를 이용하여 $\mathrm{p}<0.05$ 수준에서 유의성을 검정하였다.

\section{결과 및 고찰}

\section{항산화 활성}

기장 $80 \%$ 메탄올 추출물 및 분획물의 $\mathrm{DPPH}$ 라디칼 소거활성과 총폴리페놀함량을 측정하였다(Table 1). 기장 $80 \%$ 메탄올 추출물의 $\mathrm{DPPH}$ 라디칼 소거활성 $\left(\mathrm{EC}_{50}\right)$ 은 $67.43 \pm 4.28 \mu \mathrm{g} / \mathrm{mL}$ 으며, 클로로포름 분획물은 $5.27 \pm 1.08$ $\mu \mathrm{g} / \mathrm{mL}, n$-부탄올 분획물은 $13.82 \pm 2.42 \mu \mathrm{g} / \mathrm{mL}$, 물층은 53.92 $\pm 5.76 \mu \mathrm{g} / \mathrm{mL}$ 이었다. 총폴리페놀함량은 $80 \%$ 메탄올 추출 물에서 $16.26 \pm 1.02 \mathrm{mg} / \mathrm{g}$ 이었으며, 클로로포름 분획물은 $9.07 \pm 0.38 \mathrm{mg} / \mathrm{g}, n$-부탄올 분획물은 $4.42 \pm 0.38 \mathrm{mg} / \mathrm{g}$, 물층은 $0.43 \pm 0.04 \mathrm{mg} / \mathrm{g}$ 이었다. 기장 $80 \%$ 메탄올 추출물에서 $\mathrm{DPPH}$ 라디칼 소거활성 및 총폴리페놀함량이 높았으나, 분획물에서 항산화 활성이 저하된 것은 용매분획에 의하 여 항산화 활성 성분이 클로로포름 분획물과 $n$-부탄올 분 획물로 분배된 것으로 판단된다.

곡류에는 약 $500 \mu \mathrm{g} / \mathrm{g}$ 정도의 페놀화합물을 함유되어 있다(Senter 등, 1983). 일반적으로 총폴리페놀함량이 높을 수록 DPPH 라디칼 소거활성도 높다고 보고한 연구결과와 유사한 경향으로 나타났다. 보리와 메밀에 함유된 cathchin 과 proanthocyanidin은 항산화 활성을 갖고 있으며, lignan 은 항산화 활성 및 항암활성을 나타내는 성분이다. 쌀에 함유된 isovitexin, phytate 성분은 항산화 활성을 갖는 것으 로 보고되었다(Ramarathanam 등, 1988; Watanabe, 1998). Ko 등(2011)에 따르면 붉은기장과 노란찰기장의 $\mathrm{DPPH}$ 라디칼 소거활성은 $19.81 \mathrm{TE} / \mathrm{g}$ 과 $21.11 \mathrm{mg} \mathrm{TE} / \mathrm{g}$, 총폴리페 놀함량은 각 $45.47 \mathrm{mg} / \mathrm{g}$ 과 $45.50 \mathrm{mg} / \mathrm{g}$ 이라 보고하였으며, Kwak 등(2004)은 기장 에탄올 추출물에서 DPPH 라디칼

Table 1. DPPH radical scavenging activity and total polyphenol contents of the methanol extract and its solvent-fractionated fractions of $P$. miliaceum

\begin{tabular}{|c|c|c|}
\hline Sample & $\begin{array}{l}\text { DPPH radical } \\
\text { scavenging activity } \\
\left(\mu \mathrm{g} / \mathrm{mL}, \mathrm{EC}_{50}\right)\end{array}$ & $\begin{array}{l}\text { Total polyphenol } \\
\text { contents }(\mathrm{mg} / \mathrm{g})\end{array}$ \\
\hline $80 \%$ methanol extract & $67.43 \pm 4.28^{2) \mathrm{a} 3)}$ & $16.26 \pm 1.02^{\mathrm{a}}$ \\
\hline Chloroform fraction & $5.27 \pm 1.08^{\mathrm{b}}$ & $9.07 \pm 0.38^{\mathrm{b}}$ \\
\hline$n$-Butanol fraction & $13.82 \pm 2.42^{\mathrm{c}}$ & $4.42 \pm 0.38^{\mathrm{c}}$ \\
\hline Aqueous fraction & $53.92 \pm 5.76^{\mathrm{d}}$ & $0.43 \pm 0.04^{\mathrm{d}}$ \\
\hline
\end{tabular}


소거활성 $\left(\mathrm{EC}_{50}\right)$ 이 $2.902 \mathrm{mg} / \mathrm{assay}$ 이었다고 보고하였다. 본 연구에서는 기장 $80 \%$ 메탄올 추출물에서 $67.43 \pm 4.28 \mu$ $\mathrm{g} / \mathrm{mL}$ 이었으며, 총폴리페놀함량은 $16.26 \pm 1.02 \mathrm{mg} / \mathrm{g}$ 으로 분 석된 연구결과와 유사하였다. Seo 등(2011)에 따르면 기장 메탄올 추출물에서 phenolic compound 18종을 분석한 결 과, 핀밀 분쇄 시료에서는 $47.75 \mu \mathrm{g} / \mathrm{g}$ ER이었고, 저온초미 분쇄 시료에서는 $72.49 \mu \mathrm{g} / \mathrm{g}$ ER이었다고 보고하였다. Kim 등(2016)에 따르면 기장에 대한 DPPH 라디칼 소거활성 연구결과 에탄올 추출물에서 농도 의존적으로 항산화 활 성이 증가하였다고 보고한 연구결과와 유사하게 나타났 다. Yen 등(1992)의 연구에 따르면 식물 중의 polyphenol은 항산화 활성, 항돌연변이원성, 식이섬유, 갈변 물질과 관련 이 있다고 보고하였다.

\section{$80 \%$ 메탄올 추출물의 항돌연변이 활성}

기장 $80 \%$ 메탄올 추출물의 항돌연변이 활성을 측정하 기 위하여 $200 \mu \mathrm{g} / \mathrm{plate}, 400 \mu \mathrm{g} / \mathrm{plate}, 600 \mu \mathrm{g} / \mathrm{plate}$ 의 농도로 S. typhimurium $\mathrm{TA} 98$ 에서 $\mathrm{AFB}_{1}$, Trp-P-1, 2-AF 돌연변이원 에 대한 돌연변이 억제 효능을 측정하였다(Fig. 1). $\mathrm{AFB}_{1}$ 을 측정한 결과, $200 \mu \mathrm{g} / \mathrm{plate} 89.5 \pm 3.6 \%, 400 \mu \mathrm{g} / \mathrm{plate} 93.3 \pm$ $1.8 \%, 600 \mu \mathrm{g} / \mathrm{plate} 95.2 \pm 2.3 \%$ 으로 측정되었으며, $600 \mu \mathrm{g} / \mathrm{plate}$ 농도에서는 $200 \mu \mathrm{g} / \mathrm{plate}$ 농도보다 약 $5.7 \%$ 돌연변이 억제 효능이 증가하였다. Trp-P-1에서는 $200 \mu \mathrm{g} / \mathrm{plate} 83.2 \pm 4.5 \%$, $400 \mu \mathrm{g} / \mathrm{plate} 89.5 \pm 4.2 \%, 600 \mu \mathrm{g} / \mathrm{plate} 89.5 \pm 1.8 \%$ 로 측정되었 으며, $600 \mu \mathrm{g} / \mathrm{plate}$ 농도에서는 $200 \mu \mathrm{g} / \mathrm{plate}$ 농도보다 약 $6.6 \%$ 돌연변이 억제 효능이 증가하였다. 2-AF는 $200 \mu \mathrm{g} / \mathrm{plate}$ $94.6 \pm 2.4 \%, 400 \mu \mathrm{g} /$ plate $96.2 \pm 2.3 \%, 600 \mu \mathrm{g} /$ plate $97.1 \pm 3.6 \%$ 로 돌연변이 억제 효능이 측정되었다. 기장 $80 \%$ 메탄올

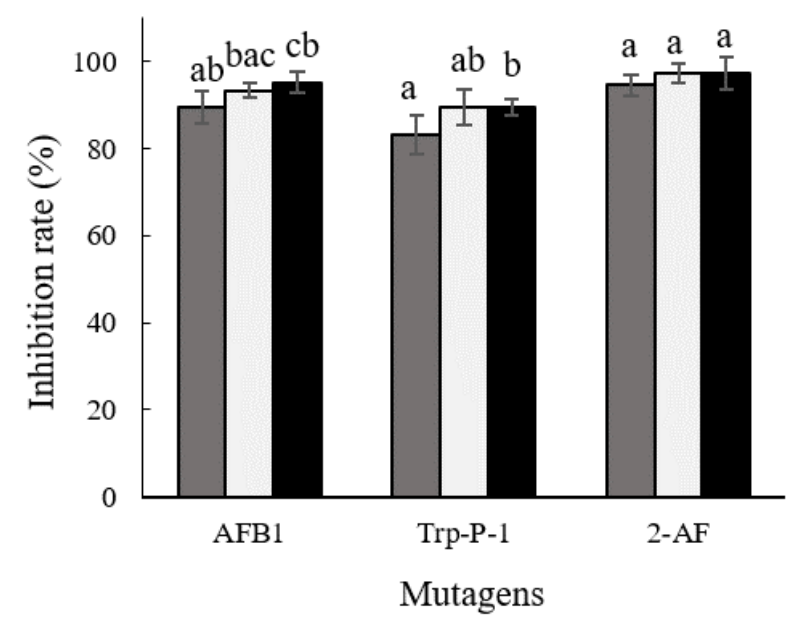

Fig. 1. Antimutagenic effects of $80 \%$ methanol extracts of $P$. miliaceum in $S$. typhimurium TA98.

$\square, 200 \mu \mathrm{g} /$ plate; $\square, 400 \mu \mathrm{g} /$ plate; $\square, 600 \mu \mathrm{g} /$ plate. Date values were expressed as mean \pm SD $(n=3)$.
추출물은 모든 처리군에서 $80 \%$ 이상 돌연변이 억제 효능 이 나타났으며, Trp-P-1에서 활성이 가장 높았다. $S$. typhimurium $\mathrm{TA} 100$ 에서 $\mathrm{AFB}_{1}, 2-\mathrm{AF}$ 에 대한 돌연변이 억제 효능은 Fig. 2 와 같다. $\mathrm{AFB}_{1}$ 을 측정한 결과, $200 \mu \mathrm{g} / \mathrm{plate}$ 에 서 $87.1 \pm 3.6 \%, 400 \mu \mathrm{g} / \mathrm{plate} \quad 88.5 \pm 3.2 \%, 600 \mu \mathrm{g} / \mathrm{plate}$ $89.8 \pm 4.5 \%$ 로 돌연변이 억제 효능이 측정되었다. $2-\mathrm{AF}$ 에서 는 $200 \mu \mathrm{g} / \mathrm{plate} 45.1 \pm 4.1 \%, 400 \mu \mathrm{g} / \mathrm{plate} 49.2 \pm 2.8 \%, 600$ $\mu \mathrm{g} / \mathrm{plate} 71.8 \pm 3.9 \%$ 로 돌연변이 억제 효능이 측정되었다. $\mathrm{AFB}_{1}$ 에서는 높은 돌연변이 억제 효능이 나타낸 반면, $2-\mathrm{AF}$ 에서는 S. typhimurium TA98에서와 달리 돌연변이 억제 효능이 낮게 나타났다.

\section{용매 분획물의 항돌연변이 활성}

$S$. typhimurium TA98에서 $\mathrm{AFB}_{1}, \mathrm{Trp}-\mathrm{P}-1,2-\mathrm{AF}$ 와 $S$. typhimurium $\mathrm{TA} 100$ 에서 $\mathrm{AFB}_{1}, 2-\mathrm{AF}^{2}$ 돌연변이원으로 하 였을 때 기장 $80 \%$ 메탄올 추출물에서 돌연변이 억제 효능 이 측정되어 기장 $80 \%$ 메탄올 추출물을 클로로포름과 $n$ 부탄올을 이용하여 용매 분획한 분획물을 $50 \mu \mathrm{g} / \mathrm{plate}$ 의 농도로 처리한 후 돌연변이 억제 효능을 측정하였다. $S$. typhimurium TA98에서 $\mathrm{AFB}_{1}, \mathrm{Trp}-\mathrm{P}-1,2-\mathrm{AF}$ 를 돌연변이원 으로 하였을 때 돌연변이 억제 효능은 Fig. 3 과 같다. 클로

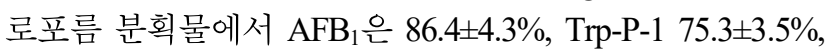
$2-\mathrm{AF}$ 에서 $18.6 \pm 3.4 \%$ 로 $\mathrm{AFB}_{1}$ 에서 돌연변이 억제 효능이 높게 나타났다. $n$-부탄올 분획물에서 $\mathrm{AFB}_{1}$ 은 $73.8 \pm 2.8 \%$, Trp-P-1 30.5 $\pm 3.6 \%$, 2-AF $13.4 \pm 3.4 \%$ 으로 측정되었다. Trp$\mathrm{P}-1$ 과 2-AF에서 돌연변이 억제 효능이 낮게 나타났지만, $\mathrm{AFB}_{1}$ 에서 돌연변이 억제 효능이 높게 나타났다. 물층에서 는 $\mathrm{AFB}_{1} 18.6 \pm 2.4 \%$, Trp-P-1 20.7 $3.1 \%, 2-\mathrm{AF} 4.2 \pm 1.5 \%$ 로

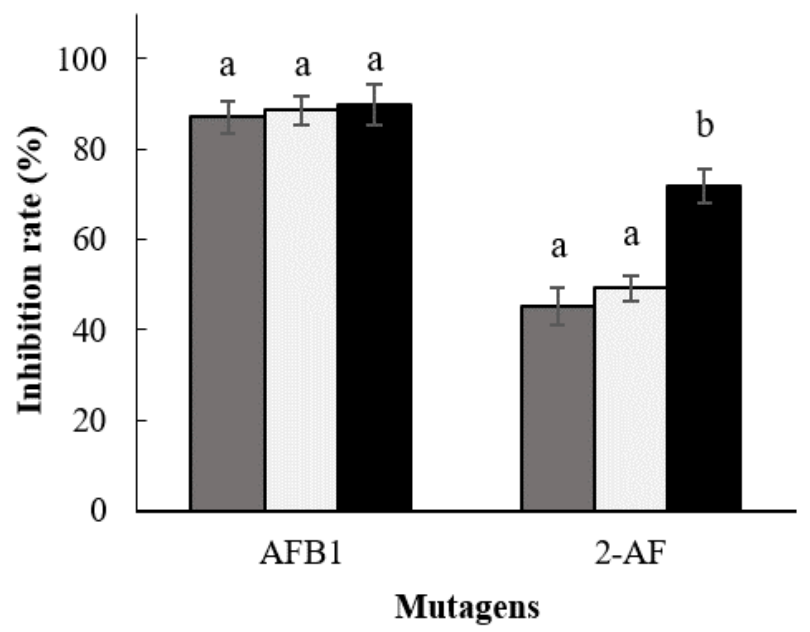

Fig. 2. Antimutagenic effects of $80 \%$ methanol extracts of $P$. miliaceum in S. typhimurium TA100.

口, $200 \mu \mathrm{g} /$ plate; $\square, 400 \mu \mathrm{g} /$ plate; $\square, 600 \mu \mathrm{g} /$ plate. Date values were expressed as mean \pm SD $(n=3)$. 


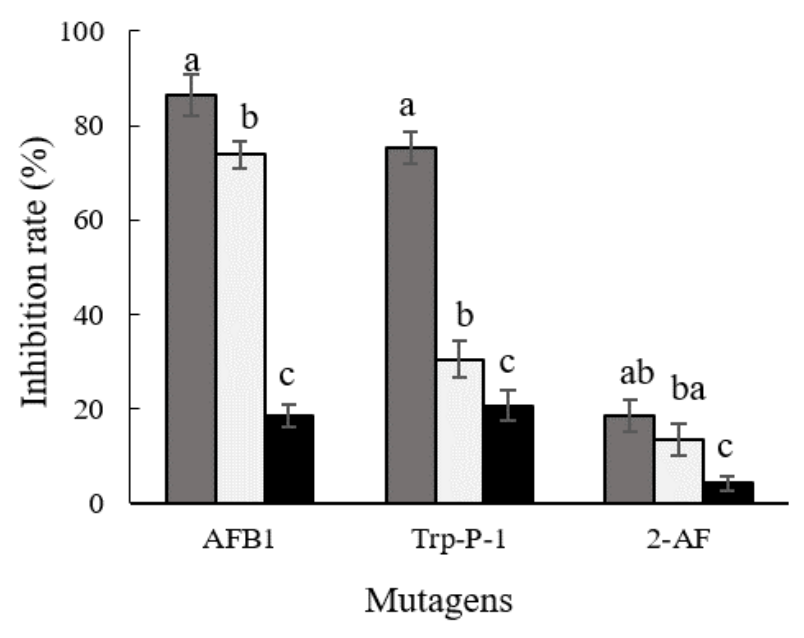

Fig. 3. Antimutagenic effects of solvent-fractionated fractions of $P$. miliaceum in $S$. typhimurium TA98.

$\square$, Chloroform Fr; $\square$, n-Butanol Fr; $\square$, Aqueous Fr. Date values were expressed as mean $\pm \mathrm{SD}(\mathrm{n}=3)$.

돌연변이 억제 효능이 낮게 나타났다. S. typhimurium TA98 에서 클로로포름 분획물, $n$-부탄올 분획물, 물층의 순으로 돌연변이 억제 효능이 나타났다. S. typhimurium TA100에 서 $\mathrm{AFB}_{1}, 2-\mathrm{AF}$ 를 돌연변이원으로 하였을 때 돌연변이 억 제 효능은 Fig. 4와 같다. 클로로포름 분획물에서 $\mathrm{AFB}_{1}$ 은 $32.6 \pm 4.3 \%, 2-\mathrm{AF} 33.5 \pm 2.5 \%$ 로 돌연변이 억제 효능이 나타 났으며, $n$-부탄올 분획물에서 $\mathrm{AFB}_{1} 8.2 \pm 1.6 \%, 2-\mathrm{AF}$ $2.4 \pm 1.3 \%$, 물층 $\mathrm{AFB}_{1}$ 은 $2.6 \pm 0.8 \%$, 2-AF $5.2 \pm 1.3 \%$ 로 돌연변 이 억제 효능이 낮게 나타났다. 돌연변이 억제 효능 성분은 대부분 클로로포름 분획물에 용해된 것으로 판단된다.

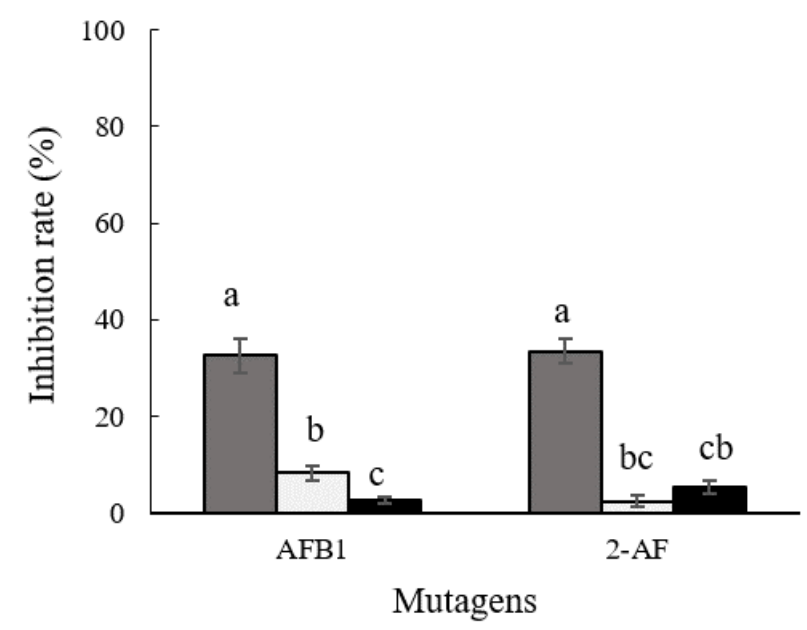

Fig. 4. Antimutagenic effects of solvent-fractionated fractions of $P$. miliaceum in S. typhimurium TA100.

$\square$, Chloroform Fr; $\square$, $n$-Butanol Fr; $\square$, Aqueous Fr. Date values were expressed as mean $\pm \mathrm{SD}(\mathrm{n}=3)$.

\section{용매 분획물의 농도에 따른 항돌연변이 활성}

S. typhimurium TA98에서 $\mathrm{AFB}_{1}, \mathrm{Trp}-\mathrm{P}-1,2-\mathrm{AF}$ 를 돌연변 이원으로 하였을 때 농도별 클로로포름 분획물과 $n$-부탄 올 분획물의 돌연변이 억제 효능을 측정하기 위하여 각 분획물을 $10 \mu \mathrm{g} / \mathrm{plate}, 25 \mu \mathrm{g} / \mathrm{plate}, 50 \mu \mathrm{g} / \mathrm{plate}, 100 \mu \mathrm{g} / \mathrm{plate}$, $150 \mu \mathrm{g} / \mathrm{plate}, 200 \mu \mathrm{g} / \mathrm{plate}$ 의 농도로 처리하였다(Fig. 5). $\mathrm{AFB}_{1}$ 에서 클로로포름 분획물에서 $80 \%$ 이상 돌연변이 억 제 효능을 나타낸 농도는 $100 \mu \mathrm{g} / \mathrm{plate} 87.7 \pm 4.2 \%, 150$ $\mu \mathrm{g} / \mathrm{plate} 89.8 \pm 4.4 \%, 200 \mu \mathrm{g} / \mathrm{plate} 94.3 \pm 1.8 \%$ 로 측정되었다. $n$-부탄올 분획물에서는 $14.8 \pm 5.6 \%-78.5 \pm 3.8 \%$ 돌연변이 억제 효능이 나타났으며, $n$-부탄올 분획물보다 클로로포 름 분획물에서 돌연변이 억제 효능이 높게 나타났다. Trp-P-1에서 클로로포름 분획물에서 $80 \%$ 이상 돌연변이 억제 효능을 나타낸 농도는 $100 \mu \mathrm{g} / \mathrm{plate}$ 에서 $84.3 \pm 7.2 \%$, $150 \mu \mathrm{g} / \mathrm{plate} 89.8 \pm 5.2 \%, 200 \mu \mathrm{g} / \mathrm{plate} 90.63 \pm 4.5 \%$ 로 측정되 었다. $n$-부탄올 분획물에서는 $2.7 \pm 1.4 \%-52.7 \pm 6.4 \%$ 돌연 변이 억제 효능이 나타났다. 2-AF에서 클로로포름 분획물 $100 \mu \mathrm{g} /$ plate에서 $32.8 \pm 5.4 \%, 150 \mu \mathrm{g} / \mathrm{plate} 40.2 \pm 6.2 \%, 200$ $\mu \mathrm{g} / \mathrm{plate} 42.8 \pm 2.6 \%$ 로 측정되었으며, $n$-부탄올 분획물에서 는 $2.7 \pm 1.4 \%-52.7 \pm 6.4 \%$ 돌연변이 억제 효능이 낮게 나타 났다. S. typhimurium TA98에서 $\mathrm{AFB}_{1}$, Trp-P-1, 2-AF에 대 한 돌연변이 억제 효능은 클로로포름 분획물에서 높게 나타났다.

S. typhimurium $\mathrm{TA} 100$ 에서 돌연변이원 $\mathrm{AFB}_{1}, 2-\mathrm{AF}$ 에 대한 돌연변이 억제 효능을 측정하였다(Fig. 6). $\mathrm{AFB}_{1}$ 에서 $80 \%$ 이상 돌연변이 억제 효능을 나타낸 클로로포름 분획 물은 $150 \mu \mathrm{g} /$ plate에서 $84.7 \pm 6.4 \%, 200 \mu \mathrm{g} /$ plate $86.4 \pm 4.2 \%$ 로 측정되었다. $n$-부탄올 분획물에서는 $3.6 \pm 1.2 \%-52.1 \pm$ $5.2 \%$ 로 돌연변이 억제 효능이 낮게 나타났다. $2-\mathrm{AF}$ 에서 $80 \%$ 이상 돌연변이 억제 효능이 나타난 클로로포름 분획 물은 $150 \mu \mathrm{g} / \mathrm{plate}$ 에서 $84.6 \pm 6.4 \%, 200 \mu \mathrm{g} /$ plate $86.2 \pm 8.6 \%$ 로 측정되었으며, $n$-부탄올 분획물에서는 $3.6 \pm 1.4 \%$ $52.1 \pm 6.7 \%$ 로 돌연변이 억제 효능이 낮게 나타났다.

현대인들의 건강에 대한 관심이 고조되면서 다양한 잡 곡류 섭취가 증가하고 있다. 기장은 단백질, 지방질, 비타 민 A 등이 풍부하여 식재료로 각광 받고 있다(Ha와 Lee, 2001; Yoon 등, 2010). 기장 $80 \%$ 메탄올 추출물과 $80 \%$ 메탄올 추출물을 계통 분획한 클로로포름 분획물에서 $\mathrm{DPPH}$ 라디칼 소거활성과 총폴리페놀 함량이 가장 높았 다. 기장에서 항산화 활성을 갖는 성분은 대부분 클로로포 름 분획물에 용해된 것을 알 수 있었으며, DPPH 라디칼 소거활성이 강할수록 총폴리페놀 함량이 높게 나타났다. 염기상치환 변이 균주인 S. typhimurium TA98에서 돌연변 이원을 $\mathrm{AFB}_{1}, \mathrm{Trp}-\mathrm{P}-1,2-\mathrm{AF}$ 로 하였을 때 클로로포름 분획 물과 $n$-부탄올 분획물에서 비교적 높은 돌연변이 억제 효능 이 나타났다. 구조돌연변이 균주인 S. typhimurium TA100에 

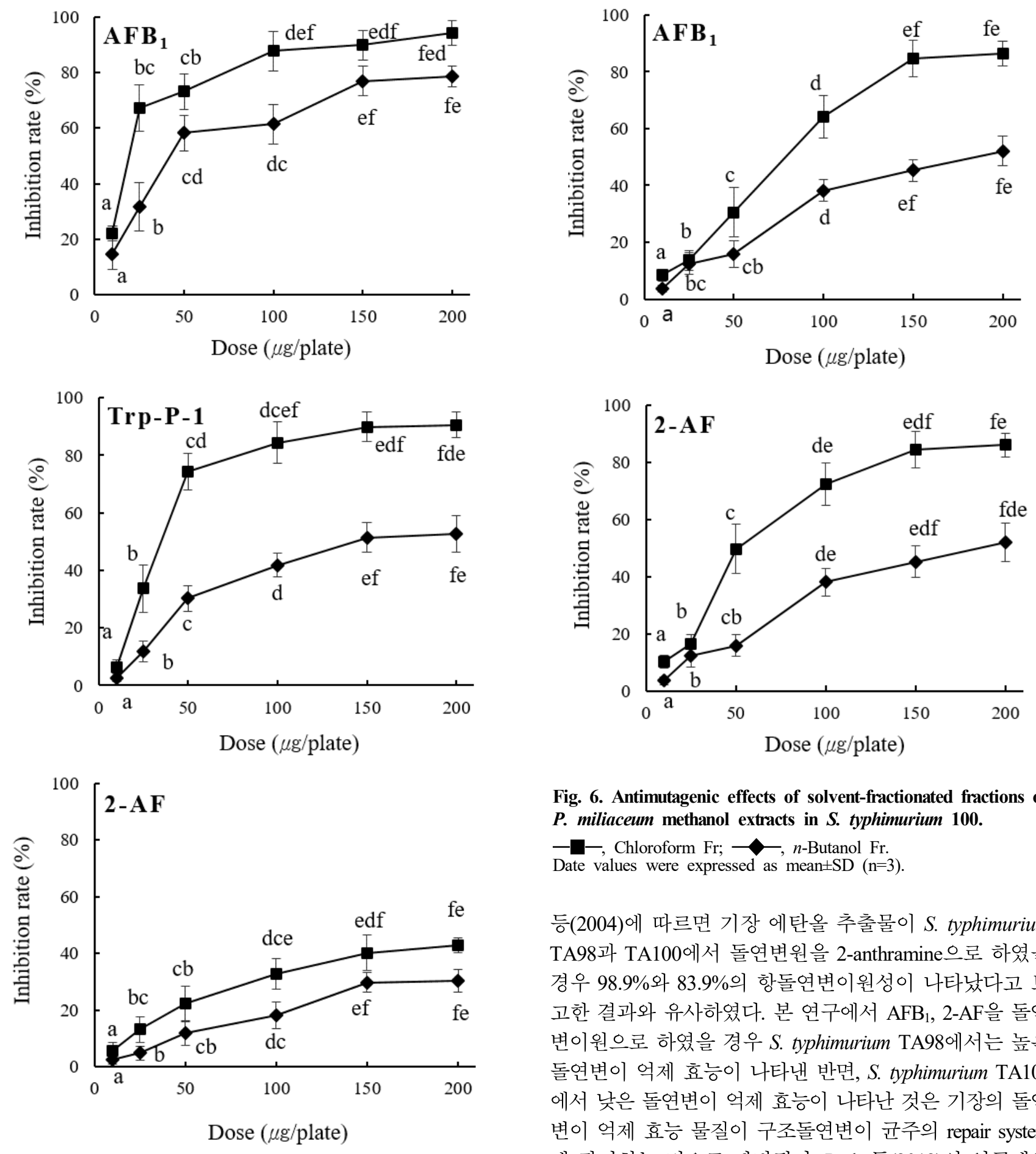

Fig. 5. Antimutagenic effects of solvent-fractionated fractions of $P$. miliaceum methanol extracts in $S$. typhimurium TA98.

$-\square-$, Chloroform Fr; —, $n$-Butanol Fr.

Date values were expressed as mean $\pm \mathrm{SD}(\mathrm{n}=3)$.

서 돌연변이원을 $\mathrm{AFB}_{1}, 2-\mathrm{AF}$ 로 하였을 경우 클로로포름 분획물에서 높은 돌연변이 억제 효능이 나타냈다. Kwak
Fig. 6. Antimutagenic effects of solvent-fractionated fractions of $P$. miliaceum methanol extracts in $S$. typhimurium 100 .

$-\square$, Chloroform Fr; $\longrightarrow$, n-Butanol Fr.

Date values were expressed as mean $\pm \mathrm{SD}(\mathrm{n}=3)$.

등(2004)에 따르면 기장 에탄올 추출물이 S. typhimurium TA98과 TA100에서 돌연변원을 2-anthramine으로 하였을 경우 $98.9 \%$ 와 $83.9 \%$ 의 항돌연변이원성이 나타났다고 보 고한 결과와 유사하였다. 본 연구에서 $\mathrm{AFB}_{1}, 2-\mathrm{AF}$ 을 돌연 변이원으로 하였을 경우 S. typhimurium TA98에서는 높은 돌연변이 억제 효능이 나타낸 반면, S. typhimurium TA100 에서 낮은 돌연변이 억제 효능이 나타난 것은 기장의 돌연 변이 억제 효능 물질이 구조돌연변이 균주의 repair system 에 관여하는 것으로 판단된다. Park 등(2012)의 연구에서 단마와 장마, 영여자 $80 \%$ 메탄올이 S. typhimurium TA98 (hisD3052)에서 1-NP, $\mathrm{AFB}_{1}, \mathrm{Trp}-\mathrm{P}-1$ 에 대한 돌연변이 억제 효능이 나타났고, 클로로포름 분획물에서 돌연변이 억제 활성이 높았다는 연구결과와 유사하였다. Bae 등(2002)에 따르면 비파의 S. typhimurium TA100 균주에 대한 돌연변 이 억제 연구에서 메탄올 추출물을 계통 분획한 클로로포름 
분획물이 돌연변이 억제 효능이 있다고 보고하였다. Yoo 등(2007)의 연구에서 살구 에탄올 추출물이 S. typhimurium $\mathrm{TA} 100$ 에 대한 항돌연변이 효능이 있다고 보고하였으며, 신나무 껍질 메탄올 추출물에서 S. typhimurium TA98과 $\mathrm{TA} 100$ 에서 $80 \%$ 이상 항돌연변이원성이 나타났다고 보고 된 결과와도 유사하였다(Oh 등, 2004). Ham 등(2004)의 S. typhimurium TA100 균주에 대한 돌연변이 효능 연구에 서 산마늘 에탄올 추출물의 처리 농도 $200 \mu \mathrm{g} / \mathrm{plate}$ 에서 $88.2 \%$ 돌연변이를 억제하였으며, 처리농도가 증가함에 따 라 억제 활성도 증가하였다는 연구결과와 유사하였다. Dashwood 등(1998)은 chlorophyll 성분의 수용성 유도체인 chlorophyllin은 세균 시험계에 있어서 heterocyclic amines, polycyclic aromatic hydrocarbons, aflatoxin 등의 돌연변이 원에 대해 돌연변이 억제 효능이 있다고 보고하였다. Kang 등(2019)은 새만금 간척지에서 적응 가능한 잡곡자 원을 선발하기 위하여 조, 기장, 수수 등 3 종에 대하여 간척지와 일반지의 생육을 비교한 결과, 수수 다음으로 기장이 높은 염과 유기물 부족, 배수 불량 등의 생육환경 과 간척지의 불량한 환경에서도 잘 생육되었다고 보고하 였다. 이와 같이 기장은 항산화 활성과 항돌연변이 활성이 우수하여 다양한 식품재료로 개발할 수 있을 것으로 판단 된다.

\section{요 약}

기장은 현대인의 건강에 유익하여 전북지역에서 재배 가 증가하고 있어 전북지역에서 생산한 기장에 대한 항산 화 활성과 항돌연변이원성을 측정하였다. 기장 $80 \%$ 메탄 올 추출물에서 $\mathrm{DPPH}$ 라디칼 소거활성 $\left(\mathrm{EC}_{50}\right)$ 은 $67.43 \pm 4.28$ $\mu \mathrm{g} / \mathrm{mL}$ 이었으며, 클로로포름 분획물은 $5.27 \pm 1.08 \mu \mathrm{g} / \mathrm{mL}, n$ 부탄올 분획물 $13.82 \pm 2.42 \mu \mathrm{g} / \mathrm{mL}$ 이었다. 총폴리페놀 함량은 $80 \%$ 메탄올 추출물에서 $16.26 \pm 1.02 \mathrm{mg} / \mathrm{g}$, 클로로포름 분획 물 $9.07 \pm 0.38 \mathrm{mg} / \mathrm{g}, n$-부탄올 분획물 $4.42 \pm 0.38 \mathrm{mg} / \mathrm{g}$ 이었다. 기장 $80 \%$ 메탄올 추출물 $(600 \mu \mathrm{g} / \mathrm{plate})$ 은 S. typhimurium $\mathrm{TA} 98$ 에서 $\mathrm{AFB}_{1} 95.2 \pm 2.3 \%$, Trp-P-1 $89.5 \pm 1.8 \%$, 2-AF $97.2 \pm 3.6 \%$ 이었으며, S. typhimurium TA100에서 $\mathrm{AFB}_{1}$ $89.8 \pm 4.5 \%, 2-\mathrm{AF} 71.8 \pm 3.92 \%$ 로 돌연변이 억제 효능이 나 타났다. S. typhimurium TA98에서 클로로포름 분획물, $n$-부 탄올 분획물, 물층의 $\mathrm{AFB}_{1}$ 효능은 $86.4 \pm 4.3 \%, 73.8 \pm 3.5 \%$, $18.6 \pm 3.4 \%$, Trp-P-1에서 $75.3 \pm 3.5 \%, 30.5 \pm 3.9 \%, 20.7 \pm 3.1 \%$ 가 나타냈다. S. typhimurium TA98에서 각 분획물의 처리 농도가 증가함에 따라 돌연변이 활성도 증가하였다. 클 로로포름 분획물의 처리농도 $200 \mu \mathrm{g} / \mathrm{plate}$ 에서 $\mathrm{AFB}_{1}$ $94.3 \pm 1.8 \%, \mathrm{Trp}-\mathrm{P}-1 \quad 90.6 \pm 4.5 \%$ 으로 측정되었다. 이와 같이 기장은 항산화 활성과 돌연변이 억제 효능을 가지고 있어 다양한 식품소재로 개발이 가능할 것으로 판단된다.

\section{감사의 글}

이 논문은 2019년도 정부(미래창조과학부)의 재원으로 “한국연구재단-전통문화융합연구사업(NRF-2016M3C1B 5907203)"과 중소벤처기업부와 한국산업기술진흥원의 “지역특화산업육성사업(R\&D, R0006163)”으로 수행된 연 구결과입니다.

\section{Conflict of interests}

The authors declare no potential conflict of interest.

\section{ORCID}

Jeong Seob Park https://orcid.org/0000-0001-6500-2865

Jong Soon Lee https://orcid.org/0000-0001-5957-4410

Jeong Ho Lee https://orcid.org/0000-0002-1052-1497

\section{References}

Bae YI, Jeong $\mathrm{CH}$, Shim KH. Nitrite-scavenging and antimutagenic effects of various solvent extract from different parts of loquet (Eriobotrya japonica Lindl). Korean J Food Preserv, 9, 92-96 (2002)

Choi KH, Yu YJ, Seo SY, Kang CH, Lee KK, Song YJ, Kim CK, Lee SY, Jung KY. Effects of sowing time on the growth and yield of proso millet (Panicum miliaceum L.) in Jeonbuk area. Korean J Crop Sci, 61, 208-214 (2016)

Dashwood R, Negishi T, Hayatsu H, Breinholt V, Hendricks J, Bailey G. Chemopreventive properties of chlorophylls towards aflatoxin B1: A review of the antimutagenicity and anticarcinogenicity data in rainbow trout. Mutat Res, 399, 245-253 (1998)

Eaton DL, Gallagher EP. Mechanism of aflatoxin carcinogenesis. Annu Rev Pharmacol Toxicol, 34, 135-172 (1994)

Ha YD, Lee SP. Characteristic of proteins in Italian millet, sorghum and common millet. Korean J Food Preserv, 8, 187-192 (2001)

Ham SS, Cui CB, Choi HT, Lee DS. Antimutagenic and cytotoxic effects of Allim victorialis extracts. Korean J Food Preserv, 11, 221-226 (2004)

Jung NJ, Kim JK, Park TS. Selection of the Excellent Barnyard Millet Variety and Technical Development for their Weediness Prevention in Paddy Rice. Final Report 
of RDA, TRKO201400011110 (2014)

Kang CH, Lee IS, Kwon SJ. Screening for fittest miscellaneous cereals for reclaimed land and functionality improvement of Sorghum bicolor cultivated in reclaimed land. Korean J Crop Sci, 64, 109-126 (2019)

Kim JH, Cho HD, Hong SM, Lee JH, Lee YS, Kim DH, Seo KI. Antioxidant and antiproliferating effects of Setaria italica, Panicum miliaceum and Sorghum bicolor extracts on prostate cancer cell lines. Korean J Food Preserv, 23, 1033-1041 (2016)

Kim MJ, Lee KH, Ko JY, Kim HJ, Lee SK, Park HY, Sim EY, Cho DH, Oh SK, Woo KS. Effect of cooking methods on cooked and antioxidant characteristics of cooked mixed grain rice with added proso millet. Korean J Food Nutr. 30, 218-225 (2017)

Kim S, Ryu JH, Kim YJ, Jeong JH, Lee SH, Oh YY, Kim YD, Kim JH. Influence of soil salinity on the growth response and inorganic nutrient content of a millet cultivar. Korean J Crop Sci, 61, 113-118 (2016)

Ko JY, Song SB, Lee JS, Kang JR, Seo MC, Oh BG, Kwak DY, Nam MH, Jeong HS, Woo KS. Changes in chemical components of foxtail millet, proso millet, and sorghum with germination. J Korean Soc Food Sci Nutr, 40, 1128-1135 (2011)

Kwak CS, Lim SJ, Kim SA, Park SC, Lee MS. Antioxidative and antimutagenic effects of Korean buckwheat, sorghum, millet and job's tears. J Korean Soc Food Sci Nutr, 33, 921-929 (2004)

Maron DM, Ames BN. Revised methods for the Salmonella mutagenicity test. Matat Res, 113, 173-215 (1983)

Middleton E, Kandaswami C. Potential health-promoting properties of citrus flavonoids. Food Technol, 48, 115119 (1994)

Oh HS, Cui CB, Choi HT, Kim SH, Jeon MS, Ham SS. Antimutagenic and cytotoxic effects of Acer ginnala Max. bark extracts. Korean J Food Preserv, 11, 550-556 (2004)

Okawa M, Kinjo J, Nohara T, Ono M. DPPH(1,1-diphenyl2-picrylhydrazyl) radical scavenging activity of flavonoids obtained from some medicinal plants. Biol Pharm Bull, 24, 1202-1205 (2001)

Ong TM, Mukhtar M, Wolf CR, Zeiger E. Differential effects of cytochrome P450-inducers on promutagen activation capabilities and enzymatic activities of S-9 from rat liver. J Environ Pathol Toxicol, 4, 55-65 (1980)

Park JS, Lee JH, Bang KS. Evaluation of antioxidant capacity and antimutagen activity of bulbil extracts of the Dioscorea japonica Decaisne and Dioscorea batatas Decaisne. Korean J Plant Res, 25, 200-208 (2012)

Ramarathanam N, Osawa T, Namiki M, Kawakishi S. Chemical studies on novel rice hull antioxidants. 1. Isolation, fractionation, and partial characterization. J Agric Food Chem, 36, $732-737$ (1988)

Rice-Evans CA, Miller NJ, Paganga G. Antioxidant properties of phenolic compounds. Trends Plant Sci, 2, 152-159 (1997)

Rimm EB, Ascherio A, Giovannucci E, Spiegleman D, Stampfer MS, Willet WC. Vegetable, fruit and cereal fiber intake and risk of coronary heart disease among men. JAMA, 275, 447-451 (1996)

Senter SD, Horvat RJ, Forbus WR. Comparative GLC-MS analysis of phenolic acids of selected tree nuts. J Food Sci, 48, 798-799 (1983)

Seo MC, Ko JY, Song SB, Lee JS, Kang JR, Kwak DY, Oh BG, Yoon YN, Nam MH, Jeong HS, Woo KS. Antioxidant compounds and activities of foxtail millet, proso millet and sorghum with different pulverizing methods. J Korean Soc Food Sci Nutr, 40, 790-797 (2011)

Singer B, Grunberger D. Moleculat Biology of Mutagens and Carcinogens. Switzerland, p 181-212 (1983)

Slinkard K, Singleton VL. Total phenol analysis: Automation and comparison with manual methods. Am J Enol Vitic, 28, 49-55 (1977)

Watanabe M. Catechines as antioxidants from buckwheat (Fagopyrum esculentum Moench) groats. J Agric Food Chem, 46, 839-845 (1998)

Weng Y, Fang C, Turesky RJ, Behr M, Kaminsky LS, Ding $\mathrm{X}$. Determination of the role of target tissue metabolism in lung carcinogenesis using conditional cytochrome P450 reductase-null mice. Cancer Res, 67, 7825-7857 (2007)

Xue W, Warshawsky D. Metabolic activation of polycyclic and heterocyclic aromatic hydrocarbons and DNA damage: A review. Toxicol Appl Pharmacol, 206, 73-93 (2005)

Yamaizumi Z, Shimoi T, Kasai H, Nishimura S, Takahashi Y, Nagao M, Sugimura T. Detection of potent mutagens, Trp-P-1 and Trp-P-2, in broiled fish. Cancer Lett, 9, 75-83 (1980)

Yen GC, Tsai LC, Lii JD. Antimutagenic effect of Maillard browning products obtained from amino acids and 
sugars. Food Chem Toxicol, 30, 127-132 (1992)

Yoo SJ, Kim SH, Jun MS, Oh HT, Choi HJ, Ham SS. Antioxidative, antimutagenic and cytotoxic effects of Prunus armeniaca extracts. Korean J Food Preserv, 14, 220-225 (2007)

Yoon ST, Jea EK, Kim YJ, Jeong IH, Han TK, Kim TY, Cho YS, Kang HW. Growth and yield characteristics of foxtail millet, proso millet and sorghum according to sowing date in middle area in Korea. Korean J Crop Sci, 60, 197-211 (2015)

Yoon ST, Lee MC, Kim JS, Zhang QU, Xu ZY, Kim YB, Kim TH, Nam JC, Nam MH, Lee YH, Hwang JB, Shim
SI, Kim SM. Growth and yield characteristics of foxtail millet, common millet cereal crops on marginal agricultural lands. Korean J Crop Sci, 55, 350-356 (2010) Yun GS, Lee JW, Hwang SG, Kim IJ, Hong ST, Ko JY, Choi GH, Kim YS, Kim HS. A high-yielding and medium maturing proso millet (Panicum miliaceum $\mathrm{L}$.) variety 'Cheongpungchal'. Korean J Breed Sci, 51, 55-60 (2019)

Zeiger E. Carcinogenicity of mutagens: Predictive capability of salmonella mutagenesis assay for rodent carcinogenicity. Cancer Res, 47, 1287-1296 (1987) 